\title{
Metodologia das Explicações Adaptacionistas
}

[Methodology of Adaptationist Explanations]

\section{Edson Cláudio Mesquita}

Resumo: O tema deste artigo está vinculado às discussões em torno do poder explicativo do programa adaptacionista que tem seu principal fundamento no processo de seleção natural. Os temas aqui apresentados e discutidos serão direcionados metodologicamente para apresentar, ao final, um arcabouço conceitual a partir do qual o adaptacionismo seja situado dentro do amplo debate acerca da evolução e, também, reconhecido como um programa de pesquisa que contribui para a biologia evolutiva, oferecendo boas explicações científicas. Entretanto, não será aqui sustentada a tese de que as explicações adaptacionistas são as mais eficazes e de maior credibilidade, dentre as alternativas existentes e que devem ser as mais utilizadas no meio científico. Diferente disso, esse estudo tentará mostrar que as explicações adaptacionistas têm seus valores cognitivos ampliados quando vinculadas às abordagens que se fundamentam em mecanismos evolutivos diferentes da seleção natural e a conhecimentos bem estabelecidos. Seu poder heurístico se expande e permite que muitos dos problemas ligados à evolução sejam melhor entendidos e analisados, com a formulação das perguntas corretas diante dos fenômenos biológicos.

Palavras-chave: adaptacionismo; evolução; seleção natural; explicação científica; valores cognitivos.

Abstract: This paper theme is linked to the discussion concerning the explanatory power of the adaptationist program, which is mainly based on the process of natural selection. The themes presented and discussed here will be methodologically outlined to present, at the end, the theoretical framework from which the adaptationism may have been located within a broad discussion on evolution. However, the thesis that adaptationist explanations are the most effective and trusted ones among other existing alternatives and that should be, therefore, the most used in the scientific circles will not be supported here. In contrast, this paper will try to show that adaptationist explanations have their cognitive values broadened when linked to approaches which are based on evolutionary mechanisms other than natural selection, as well as well-established knowledge. Its heuristic power is expanded and will allow us to really understand and analyze many of the problems of evolution together with the formulation of the right questions concerning the biological phenomena.

Keywords: adaptationism; evolution; natural selection; scientific explanation; cognitive values.

\footnotetext{
${ }^{\star}$ Professor do Colégio Militar Dom Pedro II. Mestre em Filosofia pela Universidade de Brasília (UnB). E-mail: edson7378@gmail.com. ORCID: https://orcid.org/0000-0002-2330-6024.
} 


\section{Apresentação do tema}

O adaptacionismo se estabeleceu como resultado dos esforços darwinianos para entender a especiação (CAPONI, 2011b) e, já há bastante tempo, é qualificado como um tipo de explicação que vem gerando muitos embates no âmbito da filosofia da biologia. Estes embates se acentuaram após as duras críticas de Gould e Lewontin (1979), direcionadas à insistente defesa da seleção natural como principal, ou mesmo exclusivo, processo evolutivo. Paralela a essa ideia, segue a perspectiva mais aceita e difundida entre os biólogos e filósofos evolucionistas de que não há um mecanismo singular que desempenha um papel preponderante em todos os casos de evolução. O processo evolutivo se dá por meio de vários outros mecanismos diferentes do da seleção natural e ainda pode ocorrer em diferentes níveis específica ou simultaneamente. (SANTILI, 2011). O pluralismo de processos, como é chamado essa perspectiva, também apresenta dificuldades epistemológicas, porém vem ganhando espaço dentro do cenário em Filosofia da Biologia. Biólogos e filósofos de vertentes distintas da adaptacionista aceitam a importância da seleção no processo de adaptação dos organismos, mas divergem quanto ao exa- gerado peso que lhe é atribuída. Seria um grande erro, diriam eles, evocar única ou principalmente, a seleção como causa das adaptações, desconsiderando, parcial ou completamente, os efeitos de outros processos como as constrições filogenéticas, a construção de nichos, a deriva, a migração etc.

Embora este artigo venha em defesa do programa adaptacionista, não haverá uma crítica ou a pretensão de ignorar o pluralismo de processos, mas indicar o campo de atuação de ambas perspectivas. Vale esclarecer, antes, que o adaptacionismo é heterogêneo. Godfrey-Smith (2001), por exemplo, identificou três tipos: (1) o empírico; (2) o explanatório e (3) o metodológico. Em linhas gerais, destacam Sepúlveda, Meyer e El-Hanin (2011), cada uma das variantes adaptacionistas acentua aspectos diferentes no que se refere ao papel da seleção natural na explicação da origem e diversificação da forma orgânica. Este artigo, em especial, destaca a variante (1), cuja perspectiva é a de dar mais importância ao mecanismo de seleção natural. Seus defensores admitem a hipótese de que a seleção natural é uma força ubíqua e poderosa que possui um poder explicativo-causal mais consistente do que as outras forças, o que facilitaria a tarefa de prever e entender os proces- 
sos evolutivos. Nesse sentido, é possível, em larga medida, explicar e predizer os efeitos do processo seletivo com base no papel desempenhado pela seleção natural, tendo em vista que nenhum outro mecanismo evolutivo tem um elevado grau de importância causal (GODFREY-SMITH, 2001).

Por conseguinte, a variante (1), pode ser entendida como um tipo de visão que faz alegações sobre o mundo biológico real. Com isso, se compromete com um posicionamento epistemológico que inclui como um dos problemas fundamentais o decidir-se sobre a verdade das teses sobre o mundo biológico, tendo, para isso, que combiná-las com modelos que contemplam observações, experimentos, hipóteses etc. Apenas assim poderá se afirmar que a seleção natural tem poder causal preponderante em comparação a outros mecanismos.

É certo que o programa adaptacionista tem o compromisso de produzir boas explicações científicas e apresentar razões de matriz epistemológica para justificar a eficácia de suas explicações. Com isso, vários problemas ligados ao poder explicativo de suas teorias vêm à tona. Nesse con- texto, cabe uma questão que se dirige, de modo geral, a qualquer tentativa de explicar os fenômenos evolutivos sob um viés científico: o que caracteriza uma explicação adaptacionista? Ou, ainda, qual o status epistemológico das explicações adaptacionistas?

As respostas às questões acima não são simples. Há muitos aspectos que devem ser levados em conta para que elas sejam bem elaboradas. Essas respostas devem estar relacionadas, por exemplo, a uma prática difundida em uma comunidade de indivíduos altamente especializados que acreditam produzir um tipo de conhecimento diferente do senso comum, da religião e dos mitos. Nesse sentido, o vínculo com um conjunto de condições mínimas garantidoras de um modo de explicação que quase todos dessa comunidade científica entendem como aceitáveis, torna-se uma exigência para elaboração das respostas às questões em foco. 1

A formulação de respostas a essas questões torna-se mais complicada quando presume-se que a biologia é um tipo de ciência diferenciada das demais; uma ciência única, nas palavras de Mayr (2005), cujo desapontamento se

\footnotetext{
${ }^{1}$ Aqui há a referência a certo tipo de metodologia aceita e aplicada no âmbito da comunidade científica que, dentre outras coisas, contempla testes empíricos que justificam ou falseiam as hipóteses formuladas; que se compromete com certos parâmetros filosóficos e, especialmente, metafísicos; e que ainda permita a formulação de explicações com poder preditivo, heurístico etc.
} 
evidenciou quando percebeu que a tradicional filosofia da ciência "era toda ela baseada em lógica, matemática e ciências físicas e que adotara a conclusão de Descartes de que um organismo nada mais é que uma máquina." (MAYR, 2005, p. 18). Essa perspectiva revela um dado curioso que marcou fortemente os filósofos e cientistas que se ocupavam com o status das explicações científicas: a filosofia da ciência se estruturou com base na crença de que todas as ciências possuíam certo grau de equivalência quanto aos seus fundamentos filosóficos e, como a maioria desses pesquisadores tinham um compromisso metafísico com o mecanicismo, a biologia também foi analisada com base nessa referência (MAYR, 2005, pp. 34-35). Essa postura dificultou o reconhecimento da biologia como ciência genuína, tendo em vista a dificuldade de encontrar leis biológicas que permitiriam aproximá-la dos moldes explicativos das ciências físicas. Uma das alternativas, então, seria reduzir a biologia à física. Sobre esse quesito, Sober também defende uma visão não reducionista da biologia:

Mesmo se as coisas vivas são feitas de matéria e nada mais, a verdade é que o vocabulário da biologia difere radicalmente do da física. [...] Embora o domínio da biologia ocorra dentro do domínio da física, o vocabulário da biologia e o da física têm pouca sobreposição. (SOBER, 2000, p. 25). . $^{2}$

Apenas com essa diferenciação simples entre biologia e física já é possível vislumbrar uma discussão interessante, referente ao fato de os biólogos apresentarem, em suas explicações, um vocabulário próprio que não se confunde com o da física. Há, nesse cenário, uma discussão entre os filósofos provincialistas e os autonomistas. Os primeiros defendem que essas diferenciações entre a Biologia e a Física podem gerar problemas inconsequentes quanto às táticas científicas de investigação; ao passo que os autonomistas asseguram que a Biologia é claramente uma ciência natural, porém, deve se colocar como independente da Física em relação aos seus métodos, objetivos e resultados sem, evidentemente, violar as leis científicas bem estabelecidas. (ROSENBERG, 1985, pp 13-36).

\footnotetext{
${ }^{2}$ Livre tradução. Todas as citações de textos em inglês ou espanhol neste artigo serão de livre tradução.
} 
Essa discussão eleva sua relevância quando são introduzidas outras distinções. A biologia evolutiva tem, por exemplo, um caráter histórico. Entretanto, Sober (2000, pp. 14-15), quando trata das explicações históricas e das fundamentadas em leis gerais, parece deixar entendido que essas diferenciações relativas ao modo de elaborar explicações científicas não são autoexcludentes. Em última instância, elas podem complementar-se e produzir explicações promissoras.

\section{Explicações científicas}

Para melhor entender a extensão das questões acima é importante partir de um conceito, minimamente aceitável, do que seja uma explicação científica, pautada em formulação de hipóteses que tenham consonância com as teorias científicas bem estabelecidas; com o intuito de responder questões sobre o porquê de um dado fenômeno acontecer de uma forma e não de outra; em determinadas condições e não em outras. Decerto, essa conceituação não abarca todas as nuances envolvidas no processo científico de explicar os fenômenos, mas ela resulta de uma longa discussão sobre o status desse processo, que tentou - e ainda tenta - diferenciá-lo de outras explicações, comumente utilizadas no âmbito da religião, dos mitos e do senso comum, por exemplo. Essa discussão já estava presente na filosofia clássica, porém apenas no século XX começou a ficar mais sofisticada, elaborada a partir de contribuições vindas desde Descartes até o Círculo de Viena. Podemos adotar, então, como um conceito mínimo de explicação científica aquele tipo que apresenta condições individualmente necessárias e conjuntamente suficientes atreladas a leis científicas explícitas ou implícitas que aumentam o seu poder explicativo e que também ajudam a entender a causação ${ }^{3}$ dos fenômenos da natureza.

\footnotetext{
${ }^{3} \mathrm{O}$ problema da causação já foi amplamente discutido no âmbito da filosofia da ciência, principalmente a partir das contribuições do filósofo empirista David Hume no século XVIII. Segundo Hume, a conexão entre as ideias se daria pelos princípios de semelhança, contiguidade, causa e efeito e, principalmente, o costume, "o último princípio que podemos assinalar em todas as nossas conclusões derivadas da experiência." (HUME, 1999, p. 61). Nessa perspectiva, todas as conjunções que fazemos de um fato com outro são arbitrárias e acidentais, na medida em que nos é permitido inferir a existência de um a partir do outro apenas por intermédio das nossas crenças obtidas em razão de sucessivas experiências. Somos capazes de observar, tão somente, um evento A seguido de outro evento B. Assim, por conta do hábito, esperamos no futuro por uma série de eventos semelhantes aos que aconteceram no passado, o que atrela nossas avaliações sobre qualquer questão de fato aos dados imediatos da memória e dos sentidos. A solução mais aceita considera que são as leis científicas que garantem a causalidade na medida em que se tornam o "cimento causal" que liga um determinado evento a outro e são elas que nos permitem fazer repetidos experimentos científicos com variáveis controláveis que chegam aos mesmos resultados ou, no mínimo, chegam a resultados bem semelhantes.
} 
(ROSENBERG, 2009, pp 37-64)

Sem ainda nos preocuparmos com os diferentes pressupostos filosóficos dessa discussão, vejamos se as condições por ela estabelecidas são satisfatórias para indicar o quanto uma explicação científica é fértil. Pensemos na seguinte explicação relatada pelo psicólogo David Barash, $\sqrt[4]{4}$ em 1976, sobre a agressividade dos pássaros azuis da montanha (Sialia sialis) durante o período de reprodução. Em seu experimento, Barash colocou, em três ocasiões distintas, dentro de intervalos de dez dias, um modelo macho de Sialia sialis próximo aos ninhos de dois casais dessa espécie no momento em que os machos saíam para forragear. A primeira ocasião foi antes de as fêmeas terem postos seus ovos e, as duas últimas, depois. Ele registrou, então, as abordagens agressivas dos machos de cada ninho direcionadas tanto para o modelo quanto para suas respectivas parceiras. $\mathrm{Na}$ primeira ocasião, em ambos os ninhos, a agressividade direcionada ao modelo era bastante alta, ao passo que, à fêmea, era baixa. Nas duas outras ocasiões a agressividade direcionada ao modelo foi diminuindo de forma constante e quase se extinguiu em relação à fêmea. Barash entendeu, então, que esse comportamento faz muito sentido em termos evolutivos. Os machos seriam mais sensíveis à presença de intrusos antes das fêmeas terem postos seus ovos do que após a postura, pois, teoricamente, seus genes estariam garantidos na próxima geração.

O resultado é consistente com as expectativas da teoria da evolução. Assim, a agressão direcionada ao macho intruso (o modelo) seria, claramente, especialmente vantajosa no início da temporada de reprodução, quando o território e os ninhos são, normalmente, defendidos... A agressiva resposta inicial à fêmea acasalada é também adaptativa, já que, dada uma situação que sugere uma alta probabilidade de adultério (isto é, a presença do modelo próximo à fêmea) e supondo que as fêmeas de reposição estão disponíveis, a obtenção de uma nova companheira aumentaria a aptidão dos machos... O declínio da agressividade machofêmea durante as fases de incubação e de cuida-

\footnotetext{
${ }^{4}$ Conforme apresentado por Gould e Lewontin (1979, pp. 588-589).
} 
dos primários com a cria (fledgling) poderia ser atribuído à impossibilidade de ser traído após os ovos terem sido postos... Os resultados são consistentes com a interpretação evolutiva. (BARASH, 1976, apud GOULD e LEWONTIN, 1979, p. 588).

Gould e Lewontin, em suas críticas direcionadas a esse tipo de explicação, diriam que a hipótese de Barash sobre o comportamento agressivo da espécie Sialia sialis seria apenas uma historieta (justso story), uma explicação ad hoc que "imuniza" 5 a teoria sobre a qual se fundamenta contra outras evidências empíricas e outras hipóteses explicativas que levam em consideração variantes diferentes das adotadas no experimento de Barash (a utilização de um modelo fêmea, por exemplo). Independentemente dessas críticas, e levando em consideração a definição de explicação científica aceita anteriormente como correta, há de se analisar aqui dois aspectos importantes correlacionados à explicação mencionada acima: se a hipótese de Barash:

(a) está de acordo com os conhecimentos científicos bem esta- belecidos;

(b) responde questões sobre $\mathrm{o}$ porquê daquela espécie de pássaro se comportar daquela forma e não de outra; naquelas condições e não em outras.

Logo no início e ao final da citação, Barash afirma que o resultado de sua pesquisa é consistente com a teoria da evolução. A maneira como ele descreve sua hipótese deixa evidente que "expectativas da teoria da evolução" ou "interpretação evolutiva" se referem à proposta adaptacionista. Diante disso, cabem os seguintes questionamentos:

(1) o programa adaptacionista produz conhecimentos científicos bem estabelecidos? e;

(2) o que é um conhecimento científico bem estabelecido?

Formuladas as respostas às questões (1) e (2), os créditos necessários para que os itens (a) e (b) também sejam respondidos serão evidenciados e, ainda, nos darão um entendimento razoável sobre um problema que permeia toda essa discussão: o caráter das explicações científicas. Por uma razão lógica, a questão (2) tem precedência sobre a (1). Dessa forma, cumpre esta-

\footnotetext{
${ }^{5}$ Termo usado por Hans Albert e indicado por Karl Popper, 1991, p. 220.
} 
belecer, em primeiro lugar, os referenciais teóricos que subsidiarão a resposta à questão (2).

Embora a resposta à questão (2) exija um grande número de referências a elementos de cunho epistemológico, metodológico, metafísico, dentre outros, não é o caso de expô-los aqui, cada qual com suas nuances. Há de se oferecer apenas alguns referenciais básicos, mas que serão suficientes para os propósitos desta discussão. Em poucas palavras, um conhecimento científico bem estabelecido é aquele aceito pela comunidade científica, em razão de seus valores cognitivos que possibilitam avaliar explicações sobre os fenômenos do mundo com base em procedimentos metodológicos instituídos por esta mesma comunidade. Por valores cognitivos, consideram-se aqui os seguintes: a) relevância; b) possibilidade de submissão a teste; c) compatibilidade com outras hipóteses bem estabelecidas; d) poderes preditivo (ou explicativo) e heurístico; e e) simplicidade. (COPI, 1978, pp. 386-391).

Dentro da proposta deste artigo há de se verificar, portanto, se o adaptacionismo, de fato, produz conhecimentos bem estabelecidos, isto é, com todos os valores cognitivos apresentados acima; e se está de acordo com a definição de ciência dada anteriormente, con- forme Rosenberg (2009). Além disso, utilizaremos o que Brandon (1995) chamou de explicações adaptacionistas idealmente completas.

Ainda no que concerne a definição de ciência dada por Rosenberg, há uma vasta discussão em Filosofia da Ciência acerca do que são as leis científicas que, para os propósitos deste artigo, seria desnecessária. Porém, para garantir um mínimo de fundamento e coerência, consideremos que as leis permitem que as explicações façam previsões sobre os fenômenos e indiquem, mesmo indiretamente, quais são as leis genuínas que, por sua vez, seriam de duas formas:

(i) leis fundamentais, cujo âmbito de aplicabilidade é ilimitado, sem restrições espaçotemporais e sem qualquer referência a objetos particulares, como as leis de Newton, teoricamente, válidas para todo o universo;

(ii) leis derivadas, cujo âmbito de aplicabilidade é limitado e restrito, como as leis de $\mathrm{Ke}$ pler que fazem menção direta ao sol. (LORENZANO, 2011, p. 58).

As do tipo (ii) devem ser derivadas ou deduzidas logicamente das do tipo (i). Nesse sentido, as leis estariam interligadas e, nessa pers- 
pectiva,

as regularidades que constituem as leis da natureza são aquelas expressas por axiomas e teoremas de um sistema dedutivo ideal do nosso conhecimento do mundo e, em particular, de um sistema dedutivo que atinge o melhor equilíbrio entre simplicidade e força. A simplicidade é necessária porque ela não permite elementos estranhos ao sistema de leis. A força é necessária porque o sistema dedutivo deve ser tão informativo quanto possível sobre as leis que regem o mundo. (Psillos, 2002, pp. 8-9).

Esse modo de encarar as leis envolve uma série de pressupostos metafísicos atinentes, por exemplo, a uma postura realista que entende que há uma estrutura causal no mundo e que devemos confiar nessa estrutura como um elemento imprescindível para nossas explicações; e, também, confiar em nossas teorias científicas por serem capazes, pelo menos em parte, de descrever corretamente essa estrutura. Evidentemente, nem todos os filósofos de- fendem esse pressuposto, muito menos a ideia de que as explicações devam estar atadas às leis e a uma rigidez metodológica (FEYERABEND, 2007). A despeito desses contrapontos, admitir-se-á que as concepções de causação, leis da natureza e explicação estão fortemente unidas. A adoção dessas pressuposições nesse contexto é uma estratégia de cunho metodológico e, portanto, não cabe uma discussão por demais especulativa acerca da utilização dessa estratégia.

Com base nos elementos mencionados acerca do que seja uma explicação científica, é possível identificar algumas falhas na explicação de Barash, tendo em vista que sua hipótese não está de acordo com parte dos critérios apontados, o que poderia nos levar a entender que as críticas direcionadas ao programa adaptacionista estão corretas e concluir que elas têm valor cognitivo inferior por não ser possível submetêlas à testes, e também não serem compatíveis com outras teorias científicas e hipóteses bem estabelecidas.

\section{Explicações Adaptacionistas Ide- almente Completas}

Até o momento é possível concluir que alguns filósofos da ciência e 
aqueles que criticam o programa adaptacionista afirmam que as historietas são explicações que negligenciam grande parte daqueles valores cognitivos caros à ciência e, além disso, adotam hipóteses calcadas em afirmações sobre eventos contingentes do passado que não possuem sustentação em leis gerais. Por essa razão, os adaptacionistas cometem, com frequência, erros como o da extrapolação, isto é, o de estender para ambientes ancestrais as condições presentes. A explicação de Barash, por exemplo, poderia receber essas críticas, tendo em vista seu compromisso com o adaptacionismo. Contudo, tais críticas poderiam ser rebatidas à medida que o adaptacionismo se aproximasse de perspectivas epistêmicas que privilegiam os valores cognitivos anteriormente citados. É o que Brandon pretende mostrar com as Explicações Adaptacionistas Idealmente Completas.

No âmbito da discussão em torno das explicações adaptacionistas, Brandon (1995) adota as sugestões de dois filósofos contemporâneos: Philip Kitcher e Wesley Salmon, para desenvolver o que ele chama de 'Explicações Adaptacionistas Idealmente Com- pletas' (doravante, EAIC). Sua tese considera dois aspectos relevantes para se compreender as explicações científicas: a) explicação do que realmente aconteceu (how-actually explanation) e b) explicação do que possivelmente aconteceu (how-possible explanation), situadas, aqui, dentro do modelo geral de explicação6. Ambas ajudariam a situar o adaptacionismo dentro do cenário científico na medida em que o tipo (a) de explicação requer a identificação das verdadeiras causas e as condições suficientes que levam ao explanandum, mostrando como os eventos, de fato, aconteceram. Ao passo que a explicação de tipo (b) como complemento da do tipo (a), identifica os elementos das causas possíveis sem se ocupar necessariamente com a representação das propriedades ou entidades do mundo real. (GRÜNEYANOFF, 2013, pp 853-854).

Conforme Brandon, podemos identificar duas concepções de explicação científica. A primeira diz respeito ao modo como uma explicação científica deve ser expressa: de forma a unificar um amplo corpo de fenômenos sob um número mínimo de generalizações (abordagem top-down, na

\footnotetext{
${ }^{6} \mathrm{O}$ modelo geral de explicação, seguindo as contribuições de Hempel e Oppenheim (1948), tem a estrutura de um argumento dedutivo, constituído pelas sentenças apresentadas como explicação de um dado fenômeno em razão das leis gerais ao qual está sujeito, bem como de certas condições antecedentes específicas (explanans) e a sentença que descreve o fenômeno a ser explicado (explanandum).
} 
terminologia de Kitcher). Nesse sentido:

o (ou quiçá um) objetivo da ciência é a construção de um quadro econômico de leis e generalizações capazes de subsumir todos os fenômenos observáveis. As explicações científicas organizam e sistematizam o conhecimento do mundo empírico, de tal modo que quanto mais sistematizado e econômico for, mais profunda é a nossa compreensão do que é explicado (BRANDON, 1995, p. 160).

A segunda concepção é a mecânico-causal, no sentido de que um fenômeno é explicado quando são expostos os mecanismos ou as causas que o produziram (abordagem bottom-up, na terminologia de Kitcher). Nas palavras de Brandon:

Este ponto de vista [mecânico-causal] entende a explicação de eventos individuais como primária, a explicação de generalizações daí decorrendo. Isto é, a explicação de generalizações científicas deriva dos mecanismos causais que produzem as regularidades. (BRANDON, 1995, p. 160).

Esses dois tipos de explicação científica podem ser entendidos como completamente díspares. É como Philip Kitcher, por exemplo, os interpreta. Outros teóricos podem amenizar esse entendimento, afirmando que, embora sejam perspectivas diferentes, há uma compatibilidade entre elas, já que cada uma oferece explicações complementares sobre um mesmo fenômeno. Para os propósitos dessa discussão, admitirse-á, como Brandon, que as explicações ofertadas por cada um desses tipos são complementares, no sentido de que são constituintes de uma única explicação sofisticada e completa de um mesmo fenômeno. Enquanto a primeira aumenta nossa compreensão de um dado fenômeno, subsumindoo a um princípio bastante geral, a segunda aumenta nossa compreensão pela descrição de relevantes mecanismos subjacentes a esse mesmo fenômeno. Além disso, ambas têm o mesmo objetivo e, quando unidas, podem captar melhor algumas das características importantes presentes nas explicações selecionistas sobre a adaptação.

Esse compromisso de Brandon 
desemboca na tentativa de produzir uma explicação mais próxima do que, em filosofia da ciência, é chamado de Explicações Idealmente Completas (EIC). Sabe-se que é muito difícil produzir uma EIC e essa dificuldade se dá, dentre outras razões, pelo fato de que nem sempre as abordagens no âmbito da filosofia da ciência, realmente têm relevância e/ou contribuem para a prática científica. (BRANDON, 1995, pp. 161-162). A despeito disso, as EIC compõem um modelo bastante útil. Primeiro porque se tem admitido, hoje, que a determinação do que é ou não predominante dentro de um ramo particular da prática científica é variável. Segundo, porque uma EIC - mesmo que não seja totalmente completa, como seu nome sugere - permite a comparação entre diferentes explicações elaboradas sobre um mesmo fenômeno. Isso facilita a identificação do que a torna incompleta, isto é, a identificação das potenciais "armadilhas" que prejudicam o correto entendimento dos eventos colocados sob sua análise. Nesse sentido, uma EIC pode ampliar o entendimento dos fenômenos.

Com base nesse pano de fundo, Brandon pretende transpor a perspectiva das EIC para o contexto adaptacionista e, assim, apresentar a Explicação Adaptacionista Idealmente Completa (EAIC).
Essa tentativa tem que assumir vários pressupostos, como o fato de que a adaptação é um conceito histórico (o que exige a apresentação de uma história causal, cuja referência é a seleção); que a adaptação se dá dentro da relação de replicadores e interagentes; que as explicações adaptacionistas devem estar focadas em dados filogenéticos (o que as deixam mais complicadas, já que esses dados não são tão precisos como os dados envolvidos em explicações de eventos físicos), dentre outros pressupostos. Nesse sentido, uma EAIC deve estar focada, em um primeiro momento, na explicação de características de populações, tendo em vista que são as populações, espécies, ou clados que, de fato, evoluem. Os indivíduos apenas morrem ou prosperam sob a ação de pressões seletivas.

Para essa empreitada, Brandon (1995, p. 165) enfatiza, então, a importância de se estipular cinco tipos de informações que devem estar presentes em uma EAIC:

(1) evidências de que a seleção, de fato, ocorreu;

(2) evidências ecológicas que expliquem porque alguns organismos são mais adaptados do que outros;

(3) evidências de que os traços resultantes da seleção são herdáveis; 
(4) informações sobre a estrutura de uma população com base nos padrões do fluxo de genes e nos padrões de ambientes seletivos;

(5) informações filogenéticas para se determinar quais características são primitivas e quais são derivadas.

Quanto ao tipo (1), existem estudos recentes que demostram a ocorrência de rápida adaptação evolutiva de populações de organismos em ambientes caracterizados por alterações antrópicas (REZNICK \& GHALAMBOR, 2001). As análises do processo de seleção em experimentos com variantes naturais e variantes introduzidas artificialmente como as pesquisas relativas à tolerância a metais pesados, à introdução de novas espécies de plantas e animais em locais cujos nichos ecológicos não os "prefiguravam", à introdução de novos hospedeiros ou fontes de alimentos, às mudanças no ambiente biofísico etc. indicam uma alteração na taxa de evolução que evidencia a ocorrência do processo evolutivo e, ainda, apontam para a conclusão de que o ambiente seletivo atual é, em importantes aspectos, similar ao ambiente seletivo do passado. Entretanto, isso pode gerar um impasse: o de extrapolar o papel do ambiente atual para ambientes ancestrais. O problema da extrapolação reside no fato de que não é possível fazer afirmações categóricas sobre o ambiente de milhões de anos atrás. Para tanto, podemos nos apegar às explicações do que possivelmente aconteceu como parte da estrutura das EAIC. Além disso, há de se confiar nas evidências históricas indiretas de seleção, como os registros fósseis, ainda que esses registros não impliquem, necessariamente, que ocorreu um processo de seleção, mas tão somente mostram a direção da mudança. De qualquer forma, com todas as informações das EAIC prontas será possível ter uma visão epistemologicamente mais robusta sobre as explicações adaptacionistas.

O foco do tipo (2) é saber o porquê de a seleção ter ocorrido, isto é, o porquê de alguns organismos serem mais adaptados do que outros, tarefa completamente diferente daquela que apenas identifica os organismos mais e menos adaptados. Quais são, então, as evidências ecológicas que indicam a ocorrência da seleção? Alguns autores, como Gould e Lewontin (1979), defendem que a resposta a esta questão exige um complexo estudo sobre as relações existentes entre o ambiente seletivo e os organismos, de diferentes espécies, envolvidos no processo de seleção, bem como evidências no nível fi- 
siológico e biomecânico. Eles contestariam Brandon e aos adaptacionistas, acrescentando a crítica de que as explicações ecológicas idealmente completas são apenas substitutos das historietas e não trazem qualquer alteração significativa para resolver o problema da extrapolação, frequentemente presente nesses tipos de abordagem. No entanto, Brandon reafirma que as explicações ecológicas devem se ocupar com as dúvidas que dizem respeito apenas ao porquê da seleção ter ocorrido; e não com os dados fisiológicos e biomecânicos dos organismos, ensejando em uma explicação de como a seleção ocorreu. Nesse sentido, o que interessa para uma EAIC concernente às informações do tipo (2) é saber por que um organismo está mais adaptado do que outro em um dado ambiente. "A seleção", completa Brandon (1995, pp. 167-168, nota 9), "pode ser simplesmente indiferente à fisiologia e à biomecânica subjacentes [aos organismos]", de tal modo que seria desnecessário incluir tais informações em uma EAIC.

É imprescindível que as variações relevantes sejam herdáveis para que a seleção natural tenha, de fato, consequências evolutivas. Esse é o princípio sobre o qual se fundamenta o tipo (3) de informação. Isso significa dizer que a pre- sença de certo traço em uma população pode ser explicado com base na herdabilidade, entendida como um requisito importante do processo evolutivo. Mas não é tão óbvio afirmar "que a herdabilidade implica variação" (Brandon, 1995, p. 168). Se em uma EAIC há o entendimento de que a seleção direcionou a fixação de uma característica relevante em uma dada população, a fundamentação dessa hipótese deve estar guiada por manipulações experimentais ou por evidências indiretas. Essas últimas são as informações do tipo (1) que podem ser baseadas, por exemplo, nos registros fósseis.

Supondo, com base em evidências históricas, que o traço $A_{1}$ substituiu o traço $A$ em alguma linhagem, seria difícil sustentar a afirmação de que os valores do traço $A$ foram herdados. Mas, pensando essas evidências sob a perspectiva de que o traço $A_{1}$ foi selecionado em um ambiente que sofreu mudanças graduais ao longo do tempo, então pode-se afirmar com mais precisão que $A_{1}$ substituiu $A$, também de forma gradual, ensejando a ideia de herança com variação. Talvez a herdabilidade (substituição do traço $A$ pelo $A_{1}$ ) fique mais evidente ainda em grupos intimamente relacionados. Entretanto, a herança de muitos traços se dá por meio de deriva; isso significa que 
o fato de $A_{1}$ ter substituído $A$ em uma linhagem não implica, necessariamente, que houve seleção do traço $A_{1}$ (BRANDON, 1995, p. 168). Nesse sentido, a deriva é um problema que as informações do tipo (3) têm que abarcar, pois nem sempre será possível ter evidências quanto à seleção de um traço presente em uma dada população.

Essa discussão acerca da herdabilidade dos traços em uma linhagem leva a entender que a elaboração de uma EAIC é complexa, na medida em que deve pressupor os aspectos genéticos da herdabilidade, como importantes elementos que afetam a evolução de um traço em uma população.

uma medida quantitativa de herdabilidade genética de algum traço em uma particular população em um ambiente particular é uma constante empírica que pode ou não permanecer à medida que a população e/ou o ambiente mudam. Para extrapolar, de forma confiável, os valores de herdabilidade, precisamos conhecer a genética subjacente. (BRANDON, 1995, p. 169).

As informações do tipo (4) ou informações sobre a estrutura das populações com base nos padrões de fluxo dos genes e nos padrões de um ambiente seletivo são aspectos que se mostram, por exemplo, em modelos de seleção de grupo e, por vezes, de parentesco. O que se pretende com a aquisição dessas informações é a identificação dos elementos que permitem produzir explicações acerca das consequências evolutivas em diferentes estruturas populacionais. Ora, se diferentes estruturas populacionais - demarcadas pelo padrão do fluxo dos genes e pelo padrão ambiental - resultam em consequências evolutivas distintas, então qualquer tentativa de explicar a adaptação dos indivíduos nessas populações tem de levar em conta essas especificidades, sob pena de produzir explicações com pouco valor epistêmico. Dentro dessa perspectiva, há de se esperar que duas populações com padrões ambientais e de fluxo dos genes idênticos ou semelhantes, também tenham consequências evolutivas idênticas ou semelhantes. Porém, estudos empíricos com base nos modelos de seleção

\footnotetext{
${ }^{7}$ No modelo interdêmico, os grupos são demes seletivamente homogêneos; no modelo intradêmico, os membros do grupo é que são os demes que ficam dispersos dentro de um pool comum de acasalamento. Nesse caso, os demes são seletivamente heterogêneos.
} 
de grupo (como o interdêmico e o intradêmico) 7 indicaram que o padrão de fluxo dos genes - por ser mais fácil de ser determinado e ser seletivamente homogêneo - é uma opção mais interessante do que o padrão de um ambiente seletivo.

Ainda persistente, um dos problemas que atinge o tipo (4) é a extrapolação. Há a necessidade de se obter dados observacionais ou experimentais, com referência às populações correntes, que permitam realizar a extrapolação de forma minimamente aceitável. Segundo Brandon, podemos assumir com alto grau de razoabilidade que as leis físicas atuais são iguais as dos ambientes ancestrais e, com base nelas é possível estimar, com certa precisão, parte da estrutura ambiental do passado que tem reflexos no fluxo dos genes de uma população. A evolução da capacidade de voar dos insetos, por exemplo, decerto, seguiu as leis da aerodinâmica e/ou da termodinâmica nos casos das fases anteriores à função de voo. Sendo assim, experimentos atuais com base em regularidades ou leis físicas são relevantes para se entender o ambiente seletivo do passado. Embora essa pressuposição seja útil para uma EAIC, ela se mostra limitada na medida em que deixa de fora vários outros elementos importantes para uma explicação evolutiva. O caso humano é espe- cialmente significativo, pois seria bastante complicado explicar nossos comportamentos egoístas e altruístas atuais com base na estrutura populacional dos primeiros hominídeos (BRANDON, 1995, p. 170).

As informações do tipo (5) nos permitem fazer hipóteses sobre uma dada característica produzida por seleção natural no passado (gênese histórica), mesmo que no presente, em vista de mudanças no regime seletivo, ela diminua a adaptatividade. Aqui pode haver uma confusão quando se ignora as diferenças existentes entre um traço adaptativo e uma adaptação. Os adaptacionistas frequentemente fazem essa confusão quando tentam explicar as características adaptativas correntes, vinculando seu valor adaptativo a algum ambiente ancestral no qual essas características teriam sido selecionadas. Dito de outra maneira, associa-se erroneamente a adaptação tanto ao "produto" - isto é, uma característica com valor adaptativo quanto ao "processo" que deu origem àquele produto. Para evitar esse tipo de confusão, é importante ter claros os conceitos de 'adaptação' e de 'adaptativo', bem como as relações possíveis entre eles. Nesses termos, entende-se que o conceito de adaptação diz respeito a uma ou mais caracterís- 
ticas favorecidas pela seleção natural por conta de sua eficácia no desempenho de um determinado papel. A essas características estão associadas histórias evolutivas de seleção. Já o conceito de adaptativo faz referência a uma ou mais características cuja fun- ção atual aumenta o sucesso reprodutivo de um organismo. (LALAND e BROWN, 2002, p. 132).

A tabela abaixo mostra as diferenças entre adaptação e adaptativo e as relações entre esses dois conceitos.

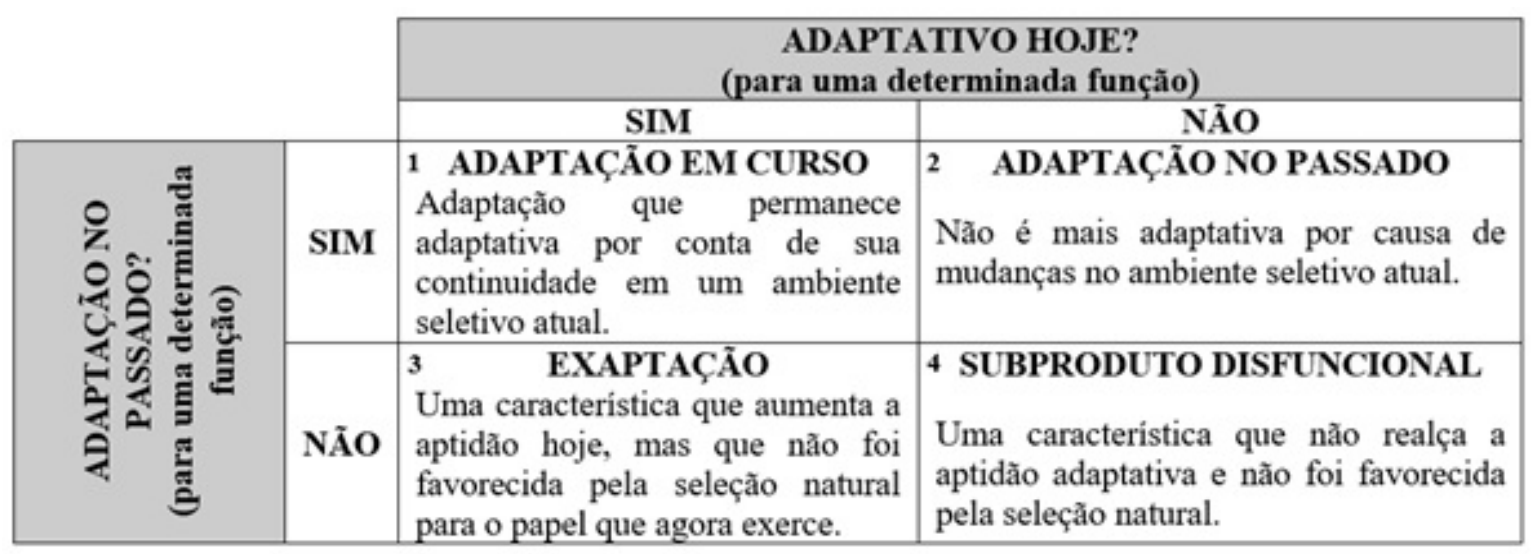

Tabela 1 - retirada de Laland e Brown, 2002, p. 133.

A tabela 1 aponta quatro situações, cada qual com suas peculiaridades, no que diz respeito às influências de características selecionadas ao longo de uma história filética qualquer. As duas células da tabela que fazem menção à adaptação em curso (1) e ao subproduto disfuncional (4) não oferecem dificuldades de entendimento. A primeira apresenta uma resposta afirmativa para adaptação no passado e para adaptativo hoje, o que significa dizer que, no passado, uma determinada função foi e continua sendo selecionada positivamente. Já a célula (4) apresenta resposta negativa para adaptação no passado e adaptativo hoje, o que implica dizer que a função não foi selecionada positivamente no passado nem o é no presente; logo, a tendência é o desaparecimento.

As outras células da tabela 1 que podem apresentar maior dificuldade de entendimento são as que fazem referência à adaptação no passado (2) e à exaptação (3). Para melhor entender a célula (2), é importante ter em mente que as características que foram selecionadas positivamente no passado e que ainda permanecem nos or- 
ganismos correntes - mas não lhe são mais adaptativas - assim o são porque as pressões seletivas atuais também são outras. Mas porque essas características ainda estão presentes? Por que a seleção natural não as eliminou? Pode ser que essas características não adaptativas sejam fruto de mutações recentes que, por alguma razão (por meio de deriva, por exemplo), se manifestaram fenotipicamente e a seleção natural não tenha tido tempo hábil para excluí-las. Uma hipótese mais plausível são as rápidas mudanças ambientais, principalmente dentro do cenário cultural humano. Nesse contexto, as mal-adaptações podem aparecer com facilidade, tendo em vista que os traços dos organismos têm por base as pressões de ambientes de outrora, cujas exigências seriam muito diferentes das correntes.

A dieta humana selecionada no Pleistoceno, por exemplo, está baseada em caça, castanhas, vegetais e frutas frescas, bem como fontes de energia com alto poder calórico como o açúcar e a gordura. O resultado dessa dieta foi o aumento da aptidão daqueles indivíduos que, além de gostar do açúcar e da gordura, não tinham problemas em digeri-los. $\mathrm{O}$ gosto por esses tipos de alimentos, evidentemente, permanece ainda hoje. Entretanto, as pressões se- letivas são outras, já que a facilidade para obter açúcar e gordura em quantidade superior ao que nossos ancestrais conseguiam é muito maior em decorrência das conquistas tecnológicas e culturais. O comportamento de alto consumo de açúcar e gordura gera grandes problemas de saúde para os indivíduos da sociedade contemporânea e, consequentemente, a diminuição da aptidão daqueles que se comportam dessa maneira.

Outro conceito que merece esclarecimento é o de exaptação (3), um termo cunhado por Gould e Vrba (1982). Conforme ilustram esses autores, estruturas complexas podem evoluir de estruturas mais simples, como características que não podem ser explicadas por pressões seletivas relacionadas à sua função atual, mas por pressões seletivas decorrentes de fatores ambientais do passado. Isso significa dizer que a exaptação é uma "característica, evoluída para outros usos (ou características não funcionais) e mais tarde cooptada para seu papel corrente", de tal modo que é possível afirmar que "as adaptações têm funções e as exaptações têm efeitos." (GOULD \& VRBA, 1982).

Para um bom entendimento desse conceito, vale à pena citar o efeito que as penas exercem hoje no voo das aves. A explicação atual mais aceita afirma que as 
penas foram inicialmente selecionadas não para o voo, mas para a termorregulação e proteção de dinossauros ancestrais das aves. O registro fóssil do Archaeopteryx mostra o que seria um dos primeiros animais com penas. Essa espécie viveu há cerca de 150 milhões de anos, possuía a dimensão de um corvo e apresentava asas e o corpo coberto de penas. Diferentemente das aves atuais, tinha dentes, ossos na cauda, como um pequeno dinossauro, e três dedos delgados em forma de garra nas extremidades de suas asas. Embora a configuração de suas garras nos pés possivelmente fosse uma adaptação para pousar em árvores e não para correr, é bem provável que não voasse, pois não possuía o esterno em forma de quilha, osso que as aves atuais possuem no peito e no qual se inserem os fortes músculos que as permitem bater as asas para alçar voo.

A espécie Archaeopteryx e outras que também possuíam penas enfrentaram ambientes com pressões seletivas bem específicas, permitindo a seleção positiva das penas para algum fim útil, a termorregulação, provavelmente. Com o passar das gerações, essas pressões se mantiveram, mas as penas, ao invés de permanecerem apenas com a função protetora, foram cooptadas para o voo, garantindo uma configuração bem semelhante às atuais aves. Por fim, o resultado foi a mudança das características das próprias penas (aerodinâmica), dos traços esqueléticos e dos padrões neuromotores específicos. Pode-se afirmar com isso que houve a exaptação de uma ou várias características ao longo da evolução das aves que permitiu o aparecimento da habilidade para o voo.

Com base ainda nas argumentações de Gould e Vrba, os adaptacionistas assumem o erro de desconsiderar as constrições filogenéticas como elementos importantes para a evolução e o desenvolvimento dos organismos. Ignoram, assim, as limitações e/ou os direcionamentos que essas contrições impõem ao processo evolutivo e à ontogenia. Por conseguinte, produzem equívocos teóricos que dificultam o correto entendimento do processo evolutivo (GOULD e LEWONTIN, 1979). Os críticos do programa adaptacionista asseguram que algumas das características presentes nos seres vivos correntes derivam não de processos ligados à seleção natural, mas de restrições estruturais que os afetam como um todo integrado.

De acordo com críticos do adaptacionismo, como Gould e Lewontin (1979), uma vez que uma dada espécie tenha "adotado" certo "caminho" evolutivo (determinada "estratégia" em detrimento 
de outras possíveis), há um compromisso cada vez maior com esta "escolha" em particular, de tal modo que ocorre uma diminuição progressiva das possibilidades de suas respostas adaptativas às exigências dos fatores ambientais. Impõe-se aí, portanto, limitações naturais em relação aos destinos evolutivos que podem ser traçados: os picos e os vales de uma paisagem evolutiva. Gould e Lewontin asseveram que essas constrições dizem respeito aos planos básicos de construção (Baupläne) dos organismos, isto é, às possibilidades de desenvolvimento (ontogenia) limitadas em decorrência das restrições históricas. Isso significa dizer que as constrições internas de uma determinada espécie a impedirão de seguir qualquer "caminho evolutivo" e/ou ontogenético.

Sobre as limitações filogenéticas e ontogenéticas dos organismos, há uma interpretação bastante recente, pautada nos pressupostos da assim chamada teoria da Evo-devo. Ela sugere uma discussão mais enfática em torno da unidade de tipo ou, em outros termos, destaca "o retorno [do] interesse pelas semelhanças que contrasta com o interesse pelas diferenças, característico tanto do darwinismo clássico quanto do darwinismo neoclássico." (CAPONI, 2011a, p. 212). Portanto, há dois problemas que merecem esclarecimentos dentro dessa perspectiva: a persistência de certas estruturas morfológicas e o surgimento de novidades morfológicas.

Esses dois problemas sempre foram analisados pelos adaptacionistas, tendo por base principal a seleção natural. O que Gould e Lewontin sugerem - e que está em concordância com a teoria da Evo-devo - é que uma explicação mais acurada do fenômeno evolutivo requer referências teóricas que estão para além do poder explicativo da seleção natural. Teria que se levar em conta "as forças que explicariam porque o padrão (pattern) morfológico gerado pela evolução só ocupa uma parte restringida de um morfoespaço que, a priori, parecia oferecer mais possibilidades do que as efetivamente atualizadas." (CAPONI, 2011a, p. 215). Essa explicação levaria em consideração, portanto, uma teoria complementar à da seleção natural capaz de explicar a sequencia, a direção e os limites impostos à filogenia dos organismos devido às exigências organizacionais da ontogênese e as constrições do desenvolvimento. Com esses três pontos, razoavelmente clarificados, seria, então, possível perceber que

o meio pelo qual se pro- 
pagam os efeitos evolutivos das contrições desenvolvimentais [...] são grupamentos de espécies que compartilham um mesmo plano básico (Bauplan); e é nesse nível que suas marcas poderão ser observadas. As constrições desenvolvimentais, com efeito, podem ser identificadas como agindo sobre todas as ordens taxonômicas que compartilham um mesmo plano corporal. (CAPONI, 2011a, p. 219).

Gould e Lewontin (1979) usam o termo em alemão 'Bauplan' porque fazem uma analogia das limitações estruturais impostas aos organismos com as limitações arquiteturais impostas a um plano de construção traçado por um engenheiro. Eles citam os arcos da Catedral de São Marcos, situada em Veneza, como exemplo. A sustentação das abóbadas dessa catedral é feita com quatro arcos. O apoio da abóbada sobre os arcos gera - devido ao seu plano de construção - espaços triangulares entre estes e a base da abóbada, chamados por Gould e Lewontin de 'tímpanos'. Esses espaços nada mais são do que subprodutos decorrentes das limitações impostas pelo Bauplan deste projeto.
Entretanto, esses tímpanos foram bem utilizados por artistas que, por meio de belas pinturas, representam mensagens da fé cristã. A beleza ímpar dessa construção e das pinturas podem levar a crer que esses espaços foram projetados exatamente para estamparem tais imagens. Esse equívoco, asseguram Gould e Lewontin, é semelhante ao equívoco dos adaptacionistas, segundo o qual, todas as características dos organismos teriam sido projetadas para cumprirem uma função em um grau ótimo.

Contrariamente a essa expectativa adaptacionista, há características nos organismos que são subprodutos (by-products) adaptativos cooptados para outras funções; à semelhança com os tímpanos da catedral de São Marcos, meros subprodutos arquitetônicos cooptados para outros fins (estampar pinturas com temáticas cristãs). Se for este o caso, a ação da seleção natural sozinha não é suficiente para causar todas as características dos organismos em uma população. Muitas delas são cooptadas (exaptação) para outros fins bem diferentes dos inicialmente projetados.

A analogia proposta acima pode ser verificada, por exemplo, no "compromisso" com o voo que a história evolutiva das aves mostra. Esse "compromisso" lhes exi- 
giu, ao longo de sua evolução, uma resposta adaptativa a um ambiente seletivo específico que, teoricamente, fomentava as habilidades para voar. Isso exigiu das aves uma arquitetura corporal com uma substancial redução de sua massa corpórea. A partir dessas informações básicas já é possível deduzir algumas constrições evolutivas, dentre as quais, a impossibilidade de adquirir um cérebro grande, com maior capacidade cognitiva. Mesmo que houvesse vantagens adaptativas em relação a essa característica em cenários mais recentes, esse traço não poderia ser selecionado positivamente, uma vez que o plano básico de construção das aves limita as possibilidades de desenvolvimento para um tipo de configuração neurofisiológica com uma grande massa encefálica.

Nestes termos, as constrições estruturais tornam-se um dos aspectos mais interessantes da contenda entre adaptacionistas e não adaptacionistas. Há o entendimento de que as restrições internas decorrentes de uma herança filética poderiam impedir que os organismos respondessem de modo ótimo às pressões ambientais, impedindo-os de seguir um "caminho evolutivo" qualquer.

Portanto, o plano de construção de cada organismo é uma das limitações que se impõem às ex- plicações com base selecionista. Gould e Lewontin (1979) acentuaram em suas críticas a negligência dos adaptacionistas diante dessas limitações filéticas. Essa atitude, aparentemente, faz com que eles não percebam que boa parte dos traços dos organismos não decorre do processo seletivo; e que o suposto poder causal-explicativo da seleção natural é mais restrito.

Dentro dessa perspectiva, pode-se afirmar que nem todas as características de um organismo que aumentam sua aptidão foram moldadas pela seleção para o papel que, hoje, desempenham. Muitas delas foram cooptadas para outros usos. Nesse sentido, deve-se fazer essa diferenciação das características que foram ou não cooptadas para outros usos com o intuito de não cair em análises equivocadas sobre o quê evoluiu do quê.

Como se vê, as críticas de Gould e Lewontin ao programa adaptacionista são bem contundentes. Porém, uma tréplica possível assumiria, em primeiro lugar, a tese de que a distinção entre exaptação e adaptação não traz grandes benefícios epistemológicos pois,

Como os processos de adaptação secundária são provavelmente muito comuns, a distinção adaptação/exaptação não é 
muito útil, exceto como uma indicação da sucessão de eventos evolutivos. Uma característica é uma adaptação para todos os propósitos a que serviu; que ajudam a explicar por que ela ainda existe. O importante não é distinguir a pressão da primeira seleção das demais, mas distinguir todo o processo de seleção do processo que ainda está acontecendo hoje, mas que não desempenha nenhum papel na evolução passada. Esta é uma distinção entre "ser adaptativo" e "ser uma adaptação". (Sterelny \& Griffiths, 1999, p 220).

Se é menos importante distinguir adaptação de exaptação do que distinguir todo o processo seletivo do processo que ocorre hoje, então outras interpretações são possíveis. A tabela 1, por exemplo, teria de ser remodelada, acentuando a importância de se entender as células 1 e 3 , substituindo o título da 1 por "ser adaptativo" e o título da 3 por "ser uma adaptação". As características de um organismo relativas à célula 3 teriam uma história evolutiva com todos, ou quase todos, os mecanismos envolvidos que possibilitaram a seleção daquelas características e aju- dam a explicar porque elas ainda existem hoje, ao passo que as características de um organismo relativas à célula 1 não poderiam, ainda, ter uma história evolutiva ou teriam apenas parte de uma história, pois "não desempenham nenhum papel na evolução passada". O programa adaptacionista tenta produzir explicações com esse viés e, por essa razão, não dá destaque para a distinção proposta por Gould e Vrba (1982). Voltando ao papel das EAIC, não podemos perder de vista que todas as informações que as compõem (1-5) possuem uma dimensão histórica. Isso significa que a tentativa de Brandon tem um caráter especulativo, o que, por si só, não a invalida em termos epistemológicos. Mesmo que esse e os outros problemas apontados levem a um posicionamento cético concernente à elaboração dessa proposta de explicação adaptacionista, Brandon entende que é possível resguardar o valor heurístico dessas explicações considerando que uma EAIC está no âmbito das explicações do que possivelmente ocorreu (how-possibly explanations). Nesse sentido, seu valor heurístico não ficaria atrelado apenas às elucidações dos processos que, de fato, ocorreram (how-actually explanation), mas também à capacidade de gerar novas perspectivas e hipóteses que contribuam 
para o enriquecimento das discussões em biologia evolutiva.

Darwin, por exemplo, já indicava que as adaptações poderiam ser explicadas a partir de histórias sobre o que possivelmente ocorreu, quando da abordagem no capítulo VI de A Origem das Espécies acerca dos órgãos de alto grau de perfeição e complexidade como os olhos. O valor heurístico dessa explicação estaria representado na grande quantidade de hipóteses e de posturas posteriormente desenvolvidas com base na teoria darwiniana. E não podemos esquecer que, em termos de explicações evolutivas, Darwin considerava a unidade de tipo inferior às condições de existência e à adaptação dos organismos. "Assim, de fato, a lei das Condições de Existência é superior, pois abarca, por meio da herança de adaptações anteriores, a lei da Unidade de Tipo." (DARWIN, 2009, p. 188).

Não obstante, o adaptacionismo não pode se subtrair do auxílio às explicações do que realmente aconteceu, sejam elas do tipo que busca a unificação, sejam elas do tipo mecânico-causal. "Nós podemos entender um fenômeno quando temos um relato completo de como realmente ele se dá" (BRANDON, 1995, p. 177). Assim, os valores cognitivos das EAIC aumentariam quando, pelo menos, parte de suas explicações estivesse amparada por uma explicação do que realmente aconteceu. Diante de hipóteses que venham a entrar em conflito com alguma lei geral, então essas hipóteses devem ser abandonadas. Não seria possível sustentar, por exemplo, uma explicação acerca da evolução da capacidade de voar dos insetos que contradissesse os princípios da aerodinâmica.

As adaptações se dão dentro de um processo histórico, cujas explicações relativas a ambientes seletivos fogem dos padrões de explicação próprios das ciências físicas. Mas isso não implica dizer que a História não é ciência. $\mathrm{O}$ que pode ser dito é que a História é um tipo de ciência diferenciada da Física e da Química. Essa particularidade define boa parte dos rumos da discussão aqui proposta. As explicações históricas têm, assim como as explicações adaptacionistas, a característica geral de fazerem referência ao que possivelmente ocorreu. Nesse sentido, qualquer tentativa, seja de base darwinista ou não, de explicar a evolução de uma determinada linhagem de organismos não pode furtar-se ao caráter histórico desse processo e sempre fará menção ao que possivelmente aconteceu, inclusive as explicações da Evo-devo propostas por Gould e Lewontin. Todavia, há de se considerar também que a evolução é um processo 
que mantem uma estrutura persistente através do espaço-tempo e que a causação física pode provocar mudanças nessa estrutura. Sendo assim, explicações baseadas nas interações causais que alteram o processo evolutivo podem mostrar-se mais robustas quando são mais precisas, aproximando as histórias de mundos possíveis às explicações do que realmente aconteceu. Essa perspectiva permite, inclusive, que sejam feitas correções e/ou ajustes em alguns aspectos dos resultados decorrentes das explicações do que realmente ocorreu. Uma via de mão dupla, por assim dizer.

Parece razoável, então, considerar que, embora as explicações de caráter histórico apresentem diferenças significativas em relação às explicações do que realmente aconteceu (baseadas em leis gerais), não há, contudo, a incidência de conflitos e contradições quando ambas são, honestamente, utilizadas. Ao contrário, elas se complementam, se ajustam e fornecem explicações epistemologicamente consistentes. Enquanto uma tenta descobrir e se guiar pelas leis gerais que governam os fenômenos, a outra se preocupa com uma sequência de eventos históricos particulares (SOBER, 2000, p. 14).

É evidente, por exemplo, a diferença entre as explicações de um físico de partículas e as de um astrônomo. Ambos fornecem explicações científicas, embora possuam formas diferentes. $\mathrm{O}$ físico se ocupará em identificar os princípios gerais que governam um tipo específico de colisão de partículas sem se preocupar com quando ou onde esse evento ocorreu, ocorre ou ocorrerá, tendo em vista que as leis gerais que regem esse tipo de fenômeno são consideradas universais (ciência nomotética); não se limitando a um local particular nem a um tempo específico. O astrônomo, por sua vez, precisa obter dados sobre um objeto único. Para tanto, informações concernentes à distância em relação à Terra, tamanho, densidade, temperatura etc. são incorporadas em sentenças que descrevem eventos históricos particulares.

Não há, portanto, uma divisão estanque entre ciência nomotética e ciência histórica; ao contrário, uma pode complementar a outra. É esse o contexto das EAIC, pois abordam tanto elementos históricos quanto nomotéticos à medida que tentam mostrar como (explicação histórica) e por que (explicação nomotética) o processo adaptativo produziu uma dada característica nos organismos de uma população específica.

Brandon exemplifica esse entendimento a partir das explica- 
ções adaptacionistas concernentes à habilidade de voar dos insetos com base em estudos realizados por Kingsolver e Koehl em 1985. Segundo Brandon, o passo inicial é dado pela resposta à seguinte pergunta: como a capacidade de voar dos insetos pode ter evoluído? A resposta, evidentemente, aponta para uma explicação do que possivelmente ocorreu. Em um resumo simplificado, uma resposta histórica plausível diria que a capacidade de voar surge de insetos não alados em decorrência de modificações graduais - dirigidas por vantagens aerodinâmicas e representadas em uma sequência que se inicia com protoasas e termina com as atuais configurações das asas - ao longo de gerações de indivíduos em uma dada população. Embora essa resposta seja facilmente criticada em razão dos avanços propiciados pela Evodevo em consonância com as contrições impostas pelo bauplan já aqui mencionadas, no momento importa apenas se fixar na ideia de que as EAIC pretendem, dentre outras coisas, ampliar os valores cognitivos das explicações adaptacionistas com o objetivo de classificá-las como boas explicações científicas.

Mesmo que, de fato, o surgimento das asas em insetos tenha se dado em razão de modificações graduais, não basta descrever uma história evolutiva das asas, indicando quais seriam as possíveis características intermediárias entre os insetos sem asas do passado e os alados de hoje. Como já foi acentuado, é importante indicar também os ganhos adaptativos durante essa transição. Para tanto, há de se identificar quais são as possíveis razões ecológicas para se afirmar, com certa precisão, que aqueles insetos com determinadas modificações fenotípicas desde os que possuíam protoasas até os que, atualmente, voam com destreza - tinham maior aptidão do que aqueles sem essas modificações. Embora uma explicação não gradual tenha a vantagem de prescindir do valor adaptativo das protoasas, afirmando que tal traço estaria situado em um vale, e não em um pico, de uma paisagem adaptativa, a explicação gradual pode trazer elementos heurísticos significativos, acrescentado a ideia de que a evolução é "criativa", tal como veremos na próxima seção.

Assim, cabe a segunda questão: por que esse processo evolutivo produziu insetos alados? A resposta a esta questão não pode ser apenas um relato histórico de possíveis eventos desconectados. Há de se construir uma explicação nomotética que faça referência à abordagem top-down e/ou à abordagem bottom-up, tendo em 
vista que os estudos de Kingsolver e Koehl foram guiados por modelos físicos, baseados nas leis da aerodinâmica e da termodinâmica. Assim, seria possível verificar o poder explicativo das EAIC ao unificar essas abordagens em uma única explicação.

Em um primeiro momento, os testes realizados em um túnel de vento não indicaram qualquer vantagem aerodinâmica significativa para as protoasas, de modo que, colocadas apenas essas condições iniciais, os insetos mutantes do passado não teriam qualquer aumento de aptidão em sua configuração fenotípica. De posse dessas informações, seria coerente abandonar as explicações do que possivelmente aconteceu sobre a evolução das asas em insetos que fossem motivadas por hipóteses acerca das vantagens aerodinâmicas das protoasas, tendo em vista que essas possíveis vantagens não foram identificadas nos testes realizados com base nas leis da aerodinâmica. Porém, são notórias as vantagens aerodinâmicas para o voo nos insetos alados contemporâneos. Então, pode-se dizer que, provavelmente, essas vantagens só se manifestaram em um estágio posterior.

Como a hipótese da vantagem aerodinâmica das protoasas não foi corroborada, outro modelo fundado nas leis da termodinâ- mica foi forjado. Neste caso, os resultados foram bastante significativos. Nos experimentos realizados foram controladas, dentre outras, as variantes referentes ao tamanho das asas e à termorregulação. Kingsolver e Koehl separaram várias amostras de asas com tamanhos e formas diferentes e as colocaram sob uma lâmpada acesa. Em seguida, eles mediram a temperatura do ar circundante e observaram que as asas produziam efeitos termorreguladores. O resultado do experimento evidenciou, portanto, vantagens importantes para os insetos concernentes à termorregulação.

Elaborar uma história evolutiva acerca dos efeitos adaptativos das películas termorreguladoras nos insetos com base apenas nesse experimento não seria, por certo, uma boa explicação científica. Como parte de uma EAIC, esse e outros experimentos teriam de estar vinculados as 5 informações mencionadas anteriormente e o conjunto total da explicação deve atender aos valores cognitivos já mencionados. Portanto, teria de ser simples, porém, relevante em razão de sua contribuição para a resposta de um problema científico importante e submetida a outros testes além dos realizados por Kingsolver e Koehl. Teria de ser, ainda, compatível com outras hipóteses bem esta- 
belecidas, embora como um contraponto à Evo-devo. Os poderes preditivo e heurístico seriam corroborados, também, pelo "poder criativo" da seleção natural, abordagem da próxima seção.

Portanto, parte do explanans de uma EAIC poderia ser composta da hipótese de que os insetos tiveram vantagens adaptativas com as protoasas em razão da termorregulação; e que os seus consequentes efeitos aerodinâmicos também resultaram no aumento da aptidão desses insetos pela capacidade de voar. Então, o que possivelmente ocorreu? A resposta a essa questão seria, em resumo, que as graduais modificações fenotípicas referentes ao aumento expressivo de tamanho da película termorreguladora (asas) garantiram uma maior aptidão para os insetos detentores dessa característica, em decorrência de uma acentuada capacidade de proteção contra as variações de temperatura em ambientes ancestrais. Essa característica posteriormente possibilitou aos insetos a aquisição de outra função, a habilidade para o voo, trazendo-lhes outros benefícios significativos que lhes garantiram, novamente, $\mathrm{o}$ au- mento da aptidão e uma melhor adaptação ao ambiente seletivo no qual se encontravam. $]^{8}$

Embora esses pontos aqui apresentados não sejam suficientes para dar firme assento a uma explicação do que realmente aconteceu, suas hipóteses podem ser testadas dentro dos limites de uma explicação do tipo que promove a unificação e/ou do tipo mecânicocausal, tendo em vista a menção às leis que orientam ou delimitam determinadas especulações próprias de uma EAIC, elevando, assim, o seu grau de plausibilidade.

Com base no que já foi destacado nessa discussão, uma reavaliação da explicação de Barash acentuaria que sua hipótese é, de fato, uma explicação histórica do que possivelmente aconteceu, quanto ao valor adaptativo da agressividade do Sialia sialis durante o período de reprodução. Entretanto, se ela estivesse inserida no contexto de uma EAIC, seu poder explicativo poderia ser aumentado, pois atenderia várias exigências colocadas por Brandon, possibilitando a elaboração de testes mais acurados. Nesse contexto, as dificuldades presentes na abordagem de Barash relati-

\footnotetext{
${ }^{8}$ Poderia ser dito - com base em Gould e Vrba (1982) - que ocorreu uma exaptação para o voo de uma característica cuja função original era completamente outra (termorregulação). Independentemente da nomenclatura utilizada, o que importa é acentuar que os experimentos baseados em leis científicas da aerodinâmica e da termodinâmica contribuíram significativamente para a elaboração de uma explicação do que possivelmente aconteceu nesse processo evolutivo.
} 
vas a outras hipóteses explicativas com base em diferentes variantes controláveis poderiam ser superadas com mais facilidade, evitando uma mera substituição por outra explicação de mesmo mote. O mais correto, então, seria incorporar os cinco tipos de conhecimentos componentes de uma EAIC, evitando os possíveis conflitos com leis naturais conhecidas e/ou conhecimentos científicos bem estabelecidos.

Pode-se dizer, então, que um adaptacionista, pautado pelas referências de uma EAIC, é capaz de formular hipóteses de acordo com os conhecimentos científicos bem estabelecidos e também responder questões sobre o porquê de um fenômeno evolutivo acontecer de uma forma e não de outra; em determinadas condições e não em outras, por meio da elucidação de condições individualmente necessárias e conjuntamente suficientes, atreladas a leis científicas explícitas ou implícitas; com consequente aumento do poder explicativo e do entendimento da causação dos fenômenos evolutivos. Nesse contexto, é possível superar, em parte, a dicotomia entre os evolucionistas que acentuam, por um lado, a seleção natural como um importante processo da evolução e, por outro, aqueles que destacam outros mecanismos.

A ideia básica até aqui, por- tanto, é a de que todos aqueles processos mencionados contribuem para o enriquecimento das explicações atinentes à adaptação dos organismos. Não obstante, considerando os objetivos desse artigo, destaca-se a ideia de que a seleção natural tem um papel importante, que a difere dos demais mecanismos evolutivos, dentro do processo que possibilita a evolução das espécies: o de ser uma "força criativa".

\section{O que o darwinismo explica?}

O título desta seção é o mesmo de um artigo que Peter GodfreySmith escreveu em julho de 2009 para o Festival Darwin, promovido pela Universidade de Cambridge. Esse artigo representa apenas uma pequena parte de uma obra mais ambiciosa, também publicada em 2009. GodfreySmith inicia seu artigo afirmando que o que Darwin fez para a biologia foi semelhante ao que Newton fez para a física. Cada qual introduziu uma teoria que unificou uma ampla gama de fenômenos, fazendo com que esses fenômenos pudessem ser explicados em termos causais sem o apelo à providência ou a propósitos. É interessante destacar essa comparação entre Darwin e Newton que os coloca no mesmo patamar 
- porque além de acentuar a importância do darwinismo para o pensamento científico, supõe que a teoria elaborada por Darwin tem todos, ou quase todos, os valores cognitivos atribuídos à teoria mecânica de Newton.

Sem mencionar os pressupostos teóricos e as abordagens desenvolvidas na obra de GodfreySmith (2009a) que, por si só requereriam um tratamento longo e complicado, este artigo destaca o que tem relevância no contexto da discussão a que se propõe: a distinção entre 1) explicações de origem e 2) explicações de distribuição. Uma explicação de distribuição pressupõe a existência de um conjunto de variantes de organismos em uma população. $\mathrm{O}$ objetivo é, então, explicar porque essas variantes têm a distribuição que têm ou porque essa distribuição sofreu modificações. Essa explicação deixa em evidência que algumas variantes de organismos são bastante comuns, enquanto outras são mais raras. Outras, ainda, teriam estado presentes em gerações passadas, mas, na atual, estão ausentes. Uma explicação de origem, ao contrário, dedica-se a explicar por que uma população veio a existir e a ter indivíduos de um tipo particular, não se importando com a quantidade nem com a distribuição desses indivíduos nessa população. Isso significa di- zer que essa explicação volta-se para o aparecimento original dos indivíduos, tomados como referência quando uma explicação do tipo (2) é dada.

Muitos biólogos diriam que a seleção natural tem papel relevante apenas nas explicações de distribuição. Com o auxílio desse mecanismo, não haveria grandes dificuldades de explicar por que uma dada característica veio a tornar-se comum ou rara em uma população de organismos. Assim como um bricoleur, a seleção natural atua em cima de coisas já existentes, no caso, as características que os indivíduos de uma população possuem. Tais características poderiam ter a frequência aumentada, diminuída ou mesmo extirpadas de um grupo de indivíduos por meio da eliminação daqueles que têm menor aptidão em um ambiente específico. A seleção, portanto, não seria capaz de produzir novidades.

A despeito desse entendimento, Godfrey-Smith admite que a seleção natural tem um papel criativo no processo evolutivo, evidenciado pelas explicações de origem. O seu grande desafio é, então, entender qual seria esse papel e como ele se vincula ao tipo (1) de explicação. Com isso, ele afirma que

as explicações de origem 
são dadas por uma parte diferente do pacote de fatores que a biologia evolutiva reconhece. As explicações de origem seriam dadas em termos do que nós chamamos de 'mutação' (junto com a recombinação de características sexuais). Elas seriam dadas em termos dos processos que, diretamente, dão origem a uma nova variação em uma população. Então, talvez, devamos dizer que o moderno darwinismo contém um pacote, e a mutação é a parte 'criativa' do pacote. A seleção é um explicador de distribuição (distributionexplainer) enquanto a mutação é um explicador de origem (originexplainer). (GODFREYSMITH, 2009b, p. 3).

Aparentemente, a abordagem de Godfrey-Smith ignora o papel do desenvolvimento na origem da variação em multicelulares. Porém, a ontogenia pode ser analisada sob outra perspectiva quando balizada por um bom conceito de sistema de herança. Os adaptacionistas, de modo geral, enfatizam a herança genética e/ou a análise das adaptações sob o ponto de vista dos genes, considerando que a herança genética está na base da evolução biológica. Cada organismo, por força de suas próprias características, responde às pressões seletivas do ambiente de forma bem particular. Em outros termos, o ambiente seleciona os indivíduos de acordo com suas características vantajosas que lhes garantem uma probabilidade maior de chegar até a fase reprodutiva e repassar sua configuração genética a seus descendentes. Assim,

Quando falamos sobre desenvolvimento é apropriado enfatizar fatores não genéticos e genéticos. Porém, quando falamos sobre unidades de seleção, exige-se uma ênfase diferente, uma ênfase nas propriedades dos replicadores... o status especial dos fatores genéticos é devido apenas a uma razão: os fatores genéticos replicam-se com defeitos (blemishes), mas os fatores não genéticos não. (DAWKINS, 1999, pp 98-99).

Nesse sentido, não há como entender a herança de informações sem levar em conta uma adequada compreensão dos fatores evolutivos que explicam, minimamente, 
a aquisição de características vantajosas por parte dos organismos em um determinado ambiente seletivo. As alterações na frequência dos alelos em uma dada população, a seleção natural, a migração, a recombinação etc. são fatores evolutivos que atuam sobre uma base genética. Para completar, a integração desses fatores, associada ao isolamento geográfico, pode levar, no transcurso do tempo, ao aparecimento de novas espécies. Esses fatores evolutivos podem ser reunidos em duas categorias:

(1) fatores que tendem a aumentar a variabilidade genética da população: mutação gênica, mutação cromossômica e recombinação;

(2) fatores que atuam sobre a variabilidade genética já estabelecida: seleção natural, migração e oscilação genética.

Para os propósitos deste artigo, um sistema de herança diz respeito à herdabilidade com alta fidelidade de traços fenotípicos e/ou informações genotípicas (codificados em DNA), constituídos ao logo de centenas de gerações que mantêm a estabilidade da variação. Os efeitos disso são o favorecimento da aptidão dos indivíduos em um determinado cenário evolutivo ou, simplesmente, por sua neutralidade, a não interferência negativa na capacidade dos indivíduos de transmitir às gerações subsequentes esses mesmos traços e/ou informações. (Abrantes e Almeida, 2011, pp. 288290). Portanto, 'herança genética' nos remete às informações que os organismos mais aptos passam a seus descendentes por meio de seu próprio DNA, considerando, inclusive, comportamentos aprendidos, ou transmitidos de uma geração para outra, tendo em vista que isso se dá em razão de uma constituição fenotípica na qual a aprendizagem ou a transmissão de comportamentos são possíveis. Deste modo,

[Ambiente] são aqueles aspectos do mundo, e apenas aqueles aspectos do mundo, que os genes fizeram evoluir em seu benefício. O resto do mundo não faz parte de qualquer ambiente. Das maneiras potencialmente infinitas de ter acesso aos recursos do mundo, os genes servem-se das adaptações dos organismos para esculpir subconjuntos [de acessos] que os organismos podem explorar para resolverem seus problemas adaptativos. (CRONIN, 2005, p. 21). 
Por 'aspectos do mundo' entendese, segundo Cronin, qualquer elemento (físico, comportamental ou cultural) que contribua para a solução dos problemas adaptativos que os organismos enfrentam. Evidentemente, essa definição de ambiente está amplamente vinculada a uma análise das adaptações centrada nos genes; e é exatamente essa análise o que possibilita uma explicação do ambiente também centrada nos genes. Considerando-se essa perspectiva correta, os ambientes são criados em decorrência de específicas adaptações dos organismos; e só com referência a essas adaptações é que se torna viável pensar em ambientes seletivos. Isso porque "sem os genes para especificar o que constitui um ambiente, os ambientes não existiriam." (CRONIN, 2005, p. 22). Seria impossível, por exemplo, definir as propriedades de um ambiente, partindo estritamente dos elementos físicos que o compõem. Para defini-las corretamente, é necessário sempre levar em conta os aspectos ligados à adaptação dos organismos que se utilizam desses recursos físicos.

Nesse sentido, o ambiente de um organismo poder ser bastante diferente do de outro; até mesmo machos e fêmeas de uma mesma espécie podem ter ambientes dife- rentes. O que determina isso é o quão e de quais regularidades ambientais (físicas, comportamentais ou culturais) os genes se utilizam para resolver os problemas adaptativos dos organismos. Assim, acrescenta Cronin, os ambientes, os organismos e suas experiências só podem ser entendidos corretamente sob o ponto de vista dos genes. Mas isso não significa que a relação entre genes, organismos e ambientes se dá apenas em uma única direção.

Os genes respondem às experiências dos organismos no mundo. A experiência regula quais genes são expressos e quando. A temperatura ambiental ou uma face sorridente pode provocar (trigger) uma reação em cadeia de genes, ativando alguns e desativando outros. Assim, os genes são vulneráveis às experiências; eles estão à mercê dos eventos no mundo exterior. (CRONIN, 2005, p. 23).

Se por um lado são os genes que possibilitam a ocorrência de adaptações em diferentes ambientes nos quais os organismos têm experiências, por outro lado, as experiências dos organismos possi- 
bilitam a ativação ou não de determinados genes. Isso significa dizer que as características dos organismos que resultam de processos adaptativos incluem, também, as suas experiências no ambiente. Elas são parte do projeto e, consequentemente, parte das especificações dadas pelos genes na configuração fenotípica dos organismos (CRONIN, 2005). A linguagem humana, por exemplo, só aparece como característica de uma pessoa, se esta pessoa, desde seu nascimento, estiver inserida em um ambiente cultural em que a linguagem é incentivada. Em outros termos, um recém-nascido humano normal possui a capacidade para o uso da linguagem já codificada em seu DNA, entretanto, a habilidade para a linguagem só aparecerá se o ambiente desta criança tiver incentivos para o aparecimento desta habilidade.

O ponto de vista de Cronin (2005) está muito próximo da proposta do fenótipo estendido de Dawkins (1999). Sob a perspectiva do gene egoísta, Dawkins entende que os efeitos fenotípicos dos genes devem ser vistos de forma ampliada, ultrapassando os limites corporais e comportamentais dos organismos. Ele apresenta o teorema central do fenótipo estendido com a seguinte sentença: um comportamento animal tende a maximizar a sobrevivência dos genes 'para' esse comportamento, quer aqueles genes se encontrem ou não no corpo do animal em particular que apresenta tal comportamento. (DAWKINS, 1999, p. 233). Embora ele acentue o comportamento dos organismos, seu teorema também vale para qualquer outra característica fenotípica como a cor da pele, o tamanho, a forma, enfim, todos os efeitos possíveis que os genes podem provocar no ambiente.

Dawkins parte do princípio de que a seleção natural não atua diretamente sobre os genes, mas sobre os efeitos fenotípicos desses genes.

O DNA encontra-se fechado num casulo de proteínas, enfaixado por membranas, protegido do mundo e invisível para a seleção natural. Se a seleção tentasse escolher diretamente moléculas de DNA, seria difícil identificar algum critério que permitisse fazê-lo. Todos os genes parecem iguais, assim como todas as fitascassete parecem iguais. (DAWKINS, 2007, p. 393).

Com isso, Dawkins quer deixar claro que a seleção natural atua de forma indireta, favorecendo aque- 
les genes que melhor manipulam o mundo - com o intuito de garantir sua propagação nas diferentes configurações das máquinas de sobrevivência dos genes (os corpos dos organismos mais aptos). À medida que há a seleção dos melhores efeitos fenotípicos, os genes que os manifestam são também selecionados. Isso significa que as unidades fundamentais da seleção natural são os replicadores e os veículos, sendo que estes últimos não se replicam, apenas se empenham para difundir seus replicadores. Ambos, evidentemente, são igualmente importantes.

O fenótipo estendido, portanto, diz respeito a todos aqueles fenômenos do mundo que só existem porque há genes que os possibilitam existir. Qual é o fenótipo dos castores, por exemplo? Com uma resposta simples, pode-se dizer: a cor do pelo, o formato do corpo, seus dentes afiados, sua habilidade aquática etc. Dawkins ainda acrescentaria a esse rol de características as árvores cortadas, as represas por eles construídas e outras mais.

Portanto, sob o ponto de vista dos genes e com a ideia de sistema de herança aqui estabelecido, o papel do desenvolvimento no processo evolutivo, conforme as contribuições da epigenética (JABLONKA e LAMB, 2010), fica vinculado às possibilidades inscritas nos genes de cada indivíduo dentro de uma população inserida em um ambiente seletivo.

Voltando à perspectiva de Godfrey-Smith e considerando-a correta, ela passa a ser especialmente importante para o adaptacionismo, já que acentua o poder do pacote darwiniano de explicar a "gênese" de qualquer espécie, bem como as características que marcam as diferenças entre as espécies, originadas a partir das diferenças dentro das espécies (GODFREY-SMITH, 2009b, p. 3). Tanto as diferenças entre as espécies quanto as que ocorrem dentro das espécies surgem devido às mutações que se acumulam em uma população de organismos. Sem elas, não há como a seleção atuar, pois é necessário que primeiro uma mudança ocorra para que haja diferenças na aptidão dos organismos de uma população. A seleção, portanto, não seria nem a causa próxima nem a causa última de um novo indivíduo.9 Já a mutação e a recombinação seriam suas causas próximas, pois elas promovem as variações dos organismos.

\footnotetext{
${ }^{9} \mathrm{~A}$ origem de um novo indivíduo não é o mesmo que a origem de uma nova espécie. A especiação pode ser explicada com base no processo de seleção natural; já quanto à origem de um novo indivíduo (como na transição dos organismos unicelulares para os pluricelulares), ainda há muitas controvérsias a respeito de uma explicação plausível e nenhuma resposta consensual.
} 
À seleção caberia remodelar uma população de maneira que uma dada variação, muito improvável de surgir, tenha maior probabilidade de ser produzida pelos mecanismos de mutação e recombinação (GODFREY-SMITH, 2009b, pp. 4-5).

Antes de continuarmos com a discussão em torno das explicações de distribuição e de origem é importante dar ênfase às discussões em torno das expressões 'causas próximas' e 'causas últimas' definidas por Ernst Mayr $(1998,2008)$, para que elas fiquem suficientemente claras, tendo em vista que Godfrey-Smith faz uso delas no contexto de sua análise. Além disso, relacionam-se com as questões que acentuaram a importância das Explicações Adaptacionistas Idealmente Completas para uma perspectiva evolucionista.

De acordo com Mayr (1998, 2008), as causas próximas têm conexão com o aqui e o agora dos fenômenos, já as causas últimas com os fatores históricos e evolutivos. As perguntas relativas às causas próximas ligam-se aos fenômenos físicos desde o nível molecular até os comportamentos dos animais e do ser humano. Para exemplificar consideremos a pergunta: como ocorre a duplicação do DNA? Ela pode ser respondida a partir da análise dos elementos químicos envolvidos nesse processo. Por sua vez, as perguntas relativas às causas últimas acentuam uma preocupação com fatores históricos que conectam as características dos organismos do passado com as do presente. É fácil observar que elas dizem respeito às adaptações e à diversidade orgânica. Por que a baleia é um mamífero aquático? Por que algumas aves migram e outras não? As respostas a essas perguntas buscam as causas últimas dos fenômenos evolutivos.

Causas próximas estão relacionadas com a função de um organismo e com suas partes, bem como com seu desenvolvimento, investigado de sua morfologia funcional até a sua bioquímica. Elas lidam com decodificação de programas genéticos e somáticos. As causas evolutivas (históricas ou últimas), por outro lado, tentam explicar por que um organismo é como é, como produto da evolução. Elas explicam a origem e a história dos programas genéticos. As causas próximas são geralmente a resposta a perguntas do tipo 'Como?', enquanto as causas últimas são geralmente a resposta a per- 
guntas do tipo 'Por quê?'. (MAYR, 2008, pp. 163164).

Embora Mayr tenha acentuado essas diferenças concernentes às causas próximas e últimas, cada qual respondendo a um tipo de pergunta específica, ambas as causas se complementam quando se tem em mente produzir explicações evolutivas. Segundo Mayr (2008, p. 165), um fenômeno biológico só pode ser, de fato, explicado se as informações relativas às suas causas próximas e últimas estiverem bem entendidas. Essa perspectiva foi exposta na seção anterior de uma forma indireta, com a assertiva de que ambas as perguntas, do tipo como e do tipo por quê, podem ser formuladas para fenômenos físicos ou históricos (SOBER, 2000). Evidentemente, não é possível negar que as hipóteses formuladas com base em uma pergunta ou outra, indicarão o tipo de explicação que melhor se adéqua a elas (mecânicocausal e/ou que promove a unificação, por um lado, e histórica, por outro). Isso porque

As causas próximas podem afetar o fenótipo, isto é, a morfologia e o comportamento; as causas últimas podem ajudar a ex- plicar o genótipo e sua história. As causas próximas são em grande parte mecânicas; as causas últimas são probabilísticas. As causas próximas ocorrem aqui e agora, em um momento particular, em um estágio particular do ciclo de vida de um indivíduo; as causas últimas têm estado ativas por longos períodos, mais especificamente no passado evolutivo de uma espécie. As causas próximas envolvem a decodificação de um programa genético ou somático existente; as causas últimas são responsáveis pela origem de novos programas genéticos e por suas mudanças. A determinação das causas próximas é geralmente facilitada pela experimentação, a das causas últimas, por inferências a partir de narrativas históricas. (MAYR, 2008, p. 166).

Como é possível observar a partir da análise de Mayr, as informações concernentes às causas próximas podem ser vinculadas às explicações do que realmente aconteceu, pois se referem, em sua maioria, aos aspectos físicos e comportamentais dos or- 
ganismos; já as ligadas às causas últimas podem ser vinculadas às explicações do que possivelmente aconteceu, pois fazem menção à história evolutiva dos organismos. Além disso, como já foi observado, elas podem se complementar, proporcionando melhores explicações acerca dos fenômenos evolutivos. Elas podem, então, compor uma EAIC, contribuindo para o seu poder explicativo.

Tanto Mayr quanto GodfreySmith parecem concordar com essas distinções e aproximações conceituais. Decerto, elas trazem reflexos positivos para as hipóteses darwinianas e, por conseguinte, para a configuração das explicações adaptacionistas. Porém, Godfrey-Smith vai além. Ele sugere que a seleção natural é suficientemente criativa para induzir o aparecimento de uma característica nova em uma população, aumentando a probabilidade de uma mutação, em particular, ocorrer. Godfrey-Smith considera que a seleção natural é capaz de remodelar o pano de fundo (background) sobre o qual a mutação e a recombinação operam, afetando o que essas fontes de variação podem produzir. Ao fazer com que uma rara sequência de genes - com possibilidades de manifestar alguma característica vantajosa para os indivíduos que a possuem - torne-se comum em uma população, a seleção amplia a probabilidade de que uma característica específica apareça.

Para ficar mais claro, pensemos essa perspectiva, aplicada ao exemplo do aparecimento das protoasas nos insetos. Suponhamos que uma população de insetos ancestrais tivesse três tipos (types) de indivíduos: X, Y e Z. Cada um deles possuía uma sequência genética com pouquíssima diferença. Os indivíduos $X$ tinham os genes $\alpha, \beta$ e $\gamma$; os indivíduos $Y$ tinham $\alpha, \beta$ e $\pi$; e os indivíduos $Z$ tinham $\alpha, \beta$ e $\varphi$. Todos esses indivíduos eram passíveis de sofrer várias mutações diferentes, uma dentre as quais, será aqui identificada pela letra grega $\vartheta$. Supõe-se, ainda, que uma dessas três configurações genéticas tem tudo o que é necessário para que sejam formadas as protoasas, exceto a mutação final $\vartheta$. A representatividade desses indivíduos na população obedecia, ainda, à seguinte distribuição: Indivíduos X, 65\%; indivíduos $\mathrm{Y}, 30 \%$ e indivíduos $\mathrm{Z}$, $5 \%$. As consequências fenotípicas para quem fosse premiado com uma mutação específica estão indicadas a seguir: 


\begin{tabular}{l|c|c|c|c|l} 
Indivíduo X (65\%): & $\alpha$ & $\beta$ & $\gamma$ & $\omega$ & Aumento de tamanho para além de 30 centímetros. \\
Indivíduo Y (30\%): & $\alpha$ & $\beta$ & $\pi$ & $\varepsilon$ & Maior resistência durante o período de estiagem. \\
\cline { 2 - 4 } Indivíduo Z (5\%): & $\alpha$ & $\beta$ & $\phi$ & $\theta$ & Aparecimento de protoasas.
\end{tabular}

Tabela 2

O primeiro aspecto que deve ser observado nesse cenário é que os indivíduos $\mathrm{X}, \mathrm{Y}$ e $\mathrm{Z}$ foram precedidos por outros que possuíam apenas os genes $\alpha$ e $\beta$ e, provavelmente, as características desses indivíduos eram adaptativas. Nas gerações posteriores, as mutações que surgiram, não necessariamente ao mesmo tempo, foram as identificadas por $\gamma, \pi$ e $\varphi$ (terceira coluna da tabela 2) que ensejaram o aparecimento dos três tipos de indivíduos nessa população idealizada, com suas respectivas diferenças de aptidão. Para os propósitos dessa exposição, considera-se que o indivíduo Z é o mais apto nesse cenário.

O segundo aspecto que merece atenção é que, no cenário acima, a probabilidade de as protoasas aparecerem é muito pequena, tendo em vista que os indivíduos do tipo $Z$ representam apenas $5 \%$ da população e, além disso, são os únicos que possuem uma configuração genética propícia para o aparecimento das protoasas. Mas é justamente em condições semelhantes a essa que o poder criativo da seleção natural se mostra. Com a seleção atuando nessa população, mantidas as mesmas exigências ambientais (ou quase todas), os indivíduos do tipo $Z$, por serem mais aptos do que os de tipo X e $\mathrm{Y}$, muito provavelmente, teriam sua representatividade aumentada em cada geração subsequente. Ao final de algumas gerações, o pano de fundo genético dessa população seria bastante diferente, já que haveria o aumento da frequência do indivíduo Z. Consequentemente, cresceria a probabilidade de as protoasas aparecerem, pois o número absoluto de espaços (slots) apropriados ${ }^{10}$ para a ocorrência da mutação $\vartheta$, que resulta no fenótipo em questão, aumentaria. (GODFREYSMITH, 2009a, p. 50).

Há de se destacar, ainda, que

\footnotetext{
${ }^{10} \mathrm{O}$ sentido de 'apropriado' neste contexto é apenas a referência ao espaço que, se preenchido pela mutação $\vartheta$, as protoasas apareceriam. É, portanto, o espaço posterior à mutação $\varphi$, ainda não preenchido na configuração genética dos indivíduos $Z: \alpha \beta \varphi_{-}$. É importante notar, ainda, que apenas o tipo $Z$ tem esse espaço apropriado.
} 
a importância da seleção natural para as explicações de origem se dá apenas quando ela afeta, em números absolutos, a quantidade dos organismos que possuem a configuração genética apropriada para o surgimento de uma determinada característica. (GODFREY-SMITH, 2009a, p. 51). Nesse sentido, mesmo que a representatividade do indivíduo $\mathrm{Y}$ aumente na mesma proporção do indivíduo $Z$, há, em termos absolutos, o aumento dos espaços apropriados para a mutação $\vartheta$. Do mesmo modo, em um cenário em que há a diminuição da quantidade dos indivíduos $\mathrm{X}, \mathrm{Y}$ e $\mathrm{Z}$ na população, mas com o consequente aumento, em termos absolutos, dos espaços apropriados para a mutação $\vartheta$, a seleção ainda mostraria seu poder criativo.

Essa perspectiva fica mais evidente quando introduzida a noção de luta pela sobrevivência, já que, como afirma Godfrey-Smith, a seleção envolve competição. Tal competição pode ser entendida em um sentido fraco ou forte. O sentido fraco pode ser exemplificado pela quantidade de descendentes que os indivíduos $\mathrm{X}, \mathrm{Y}$ e $Z$ deixam nas gerações subsequentes. Se, em cada geração, os indivíduos $Z$ aumentam sua representatividade na população em detrimento dos indivíduos X e Y, então, os espaços (slots) que podem ser preenchidos nos indivíduos Z, não poderiam sê-lo nos outros. Em um sentido forte, a competição envolve outros elementos. Há de se pensar na dependência causal entre os indivíduos, afetando a sua reprodução. Se o indivíduo $Z$ é bem sucedido sob a ação da seleção natural, isso implica não apenas que ele deixa um maior número de descendentes em comparação aos outros, mas, também, uma maior quantidade de descendentes do que ele teria tido se a seleção não o tivesse favorecido. "A competição entre tipos (types) só é importante para as explicações de origem, na medida em que o 'vencedor' é capaz de produzir mais, em números absolutos, do que seria de outro modo." (GODFREYSMITH, 2009a, p. 51).

Com a mutação $q$ acrescida à configuração genética do indivíduo $Z$, teríamos outro indivíduo, $Z_{1}$. Como a aquisição das protoasas é uma vantagem concernente à termorregulação, essa característica, possivelmente, seria fixada nas gerações ulteriores. A seleção natural, então, agiria novamente e aumentaria na população a frequência dos espaços apropriados para a introdução de uma nova mutação, $\eta$, cujos efeitos fenotípicos são benéficos. Com a introdução da mutação $\eta$, os indivíduos que a adquirissem teriam, por exemplo, o tamanho das pro- 
toasas aumentado. Esse processo seguiria até que, em um determinado momento, a população de insetos seria formada por indivíduos com a seguinte configuração genética:

\begin{tabular}{|l|l|l|l|l|l|l|}
\hline$\alpha$ & $\beta$ & $\phi$ & $\theta$ & $\eta$ & $\chi$ & Insetos com asas e capazes de voar. \\
\hline
\end{tabular}

Tabela 3

"Assim, apesar da estranheza inicial da ideia, a seleção pode ser uma força 'criativa' da evolução, embora seja verdade que, em todo o caso, 'para ser selecionada, uma mudança deve ser produzida primeiro'”. (GODFREYSMITH, 2009b, p. 5). A configuração genética mostrada na tabela 2 seria, portanto, o resultado não apenas de uma mera acumulação de mutações que aumentam a aptidão dos indivíduos que as possuem, mas, também, da ação criativa da seleção que remodela o pano de fundo genético sobre o qual as mutações atuam, permitindo o aparecimento de uma determinada característica fenotípica nos organismos. ${ }^{11}$

Essa perspectiva se destaca por apresentar o poder criativo da se- leção natural quando ela atua sobre um pano de fundo genético pré-existente. Se isso é verdade, a seleção passa a ser um processo evolutivo com status diferenciado em relação aos outros, o que contribui para a defesa da abordagem adaptacionista em questão. A plausibilidade dessas ideias pode fazer com que as explicações adaptacionistas adquiram um status epistemológico mais confiável a medida que se vinculam aos elementos teóricos apresentados neste artigo concernente às EAIC. Com a ideia de que a seleção natural possui uma "forca criativa" capaz de remodelar o pool genético de uma dada população, a relevância desse mecanismo evolutivo passa a vigorar no mesmo nível dos outros, au-

\footnotetext{
${ }^{11}$ Evidentemente, esse cenário ideal é uma experiência de pensamento. Aqui são desconsideradas as contingências de uma situação real. Essas contingências poderiam influir tão profundamente em uma situação semelhante, que os resultados seriam completamente outros. O ambiente, por exemplo, está sujeito a vários tipos de modificações que alteram as pressões seletivas. Uma mudança pequena que viesse a favorecer o indivíduo Y dificultaria, provavelmente, o aparecimento das protoasas em favor da resistência à estiagem.
} 
mentando a importância das contribuições teóricas do programa adaptacionista para as explicações pautadas no pluralismo de processos.

Toda essa discussão nos leva a uma reavaliação do programa adaptacionista que acrescenta ao seu arcabouço conceitual outros elementos de cunho epistemológico e metodológico, debatidos ao longo dessa análise, e que são aceitos por grande parte da comunidade científica. Com esses elementos é possível notar, mesmo que de forma geral, os vínculos que as explicações adaptacionis- tas podem ter com conhecimentos bem estabelecidos de outras áreas da ciência que as tornam mais plausíveis e com seus valores cognitivos ampliados. Assim, fica mais fácil reavaliar as críticas que o adaptacionismo vem recebendo desde a publicação do artigo de 1979 de Gould e Lewontin, bem como justificar, sob o ponto de vista filosófico, a adoção desse programa em vários estudos contemporâneos, seja no âmbito puramente biológico, seja com referência à evolução cultural e/ou da cultura.

\section{Referências}

ABRANTES, P. \& ALMEIDA, F. Evolução Humana: A Teoria da Dupla Herança. Em: ABRANTES, P. [et al.]. Filosofia da Biologia. Porto Alegre: Artmed, 2011, 261-295.

BRANDON, R. Adaptation and Environment. New Jersey: Princeton University Press, 1995.

CAPONI. G. Aproximação Epistemológica à Biologia Evolutiva do Desenvolvimento. Em: ABRANTES, P. Filosofia da Biologia. Porto Alegre: Artmed, 2011a, pp. 211-223.

La Segunda Agenda Darwiniana: contribución preliminar a la historia del programa adaptacionista. México, DF: Centro de Estudios Filosóficos, Políticos y Sociales Vicente Lombardo Toledano, $2011 \mathrm{~b}$.

COPI, I. Introdução à Lógica. São Paulo: Mestre Jou, 1978.

CRONIN, H. Adaptation: a critique of some current evolutionary thought. Em: The Quarterly Review of Biology. London: Centre for Philosophy of Natural and Social Science, 80 (1), 2005, pp. 19-26.

DARWIN, C. On the Origin of Species. London: Penguin Books, 2009.

DAWKINS, R. The Extended Phenotype: the long reach of the gene. New York: Oxford University Press, 1999.

O Gene Egoísta. São Paulo: Companhia das Letras, 2007.

FEYERABEND, P. Contra o Método. São Paulo: Editora UNESP, 2007.

GODFREY-SMITH, P. Darwinian Populations and Natural Selection. New York: Oxford University Press, 2009a.

What Darwinism Explains. Cambridge: University of Cambridge, for the Darwin Festival, july 2009b. Disponível em: < https://www.researchgate.net/publication/265880015_What_Darwinism_Explains $>$. Acesso em: 10 mar. 2011.

GOULD, S. J. \& LEWONTIN, R. C. The Spandrels of San Marco and the Panglossian Paradigm: a critique of the adaptationist programme. Londres: Proc. R. Soc. B 205, 1979, pp. 581-598.

GOULD, S. J. \& VRBA, E. Exaptation - a missing term in the science of form. Boulder: Paleobiology, vol. 8, $\mathrm{n}^{\mathrm{o}} 1,1982$, pp. $4-15$. 
GRÜNE-YANOFF, T. Appraising models nonrepresentationally. Chicago: The University of Chicago Press, 2013. Disponível em: $<$ https://www.jstor.org/stable/10.1086/673893?seq=1>. Acesso em: 30 de mai.2018.

HEMPEL C. G. \& OPPENHEIM P. Studies in the Logic of Explanation. Philosophy of Science, 1948. Diponível em: < http://citeseerx.ist.psu.edu/viewdoc/summary?doi=10.1.1.294.3693>. Acesso em: 6 de jun. 2018.

HUME, D. Investigação Acerca do Entendimento Humano. Nova Cultural, Os Pensadores, São Paulo, 1999.

JABLONKA, E. e LAMB, M. J. Evolução em Quatro Dimensões. São Paulo: Companhia das Letras, 2010.

LALAND, K. N. \& BROWN, G. R. Sense and Nonsense: Evolutionary Perspectives on Human Behaviour. New York: Oxford University Press, 2002.

LORENZANO, P. Leis e Teorias em Biologia. Em: ABRANTES, P. Filosofia da Biologia. Porto Alegre: Artmed, 2011, pp. 53-82.

MAYR, E. O Desenvolvimento do Pensamento Biológico. Brasília: UnB, 1998. Biologia, Ciência Única. São Paulo: Companhia das Letras, 2005. Isto é Biologia: A Ciência do Mundo Vivo. São Paulo: Companhia das Letras, 2008.

POPPER, K. A Demarcação Entre Ciência e Metafísica. Em: CARRILHO, M. Epistemologia: Posições e Críticas. Lisboa: Calouste Gulbenkian, 1991, pp. 201-265.

PSILLOS, S. Causation \& Explanation. Montreal \& Kingston: McGill-Queen's University Press, 2002.

REZNICK, D. N. \& GHALAMBOR, C. K. The population ecology of contemporary adaptations: what empirical studies reveal about the conditions that promote adaptive evolution. Riverside: University of California, 2001. Disponível em: <https://biology.ucr.edu/ucirpee/ReznickGhalambor2001.pdf $>$. Acesso em: 6 de jun. 2018.

ROSENBERG, A. The Structure of Biological Science. New York: Cambridge University Press, 1985. Introdução à Filosofia da Ciência. São Paulo: Loyola, 2009.

SANTILLI, E. Níveis e unidades de seleção: o pluralismo e seus desafios filosóficos. Em: ABRANTES, P. Filosofia da Biologia.Porto Alegre: Artmed, 2011, pp. 193-210.

STERELNY, K \& GRIFFITHS, P. E. Sex and death: an introduction to philosophy of biology. Chicago: The University of Chicago Press, 1999.

SEPÚLVEDA, C. \& MEYER D. \& EL-HANI, C. Adaptacionismo. Em: ABRANTES, P. Filosofia da Biologia.Porto Alegre: Artmed, 2011, pp. 162-192.

SOBER, E. Philosophy of Biology. $2^{\text {nd }}$ edition, Boulder: Westview Press, 2000.

Recebido: 08/10/2019

Aprovado: $11 / 01 / 2020$

Publicado: $26 / 01 / 2020$ 
